Article

\title{
Can Low-Cost Unmanned Aerial Systems Describe the Forage Quality Heterogeneity? Insight from a Timothy Pasture Case Study in Southern Belgium
}

\author{
Adrien Michez ${ }^{1, *(\mathbb{D}}$, Lejeune Philippe ${ }^{1}\left(\mathbb{D}\right.$, Knoden David $^{2}$, Cremer Sébastien ${ }^{3}$, \\ Decamps Christian ${ }^{4}$ and Jérôme Bindelle ${ }^{5}$ (D) \\ 1 TERRA Teaching and Research Centre (Forest is Life), Gembloux Agro-Bio Tech, University of Liege, \\ Passage des Déportés 2, 5030 Gembloux, Belgium; p.lejeune@uliege.be \\ 2 Fourrages Mieux ASBL, Horritine 1, 6600 Bastogne, Belgium; knoden@fourragesmieux.be \\ 3 Centre de Michamps, ASBL, Horritine 1, 6600 Bastogne, Belgium; sebastien.cremer@uclouvain.be \\ 4 UCLouvain, Earth and Life Institute, Université catholique de Louvain, Croix du Sud 2, 1348 \\ Louvain-la-Neuve, Belgium; christian.decamps@uclouvain.be \\ 5 TERRA Teaching and Research Centre (AgricultureIsLife), Gembloux Agro-Bio Tech, University of Liege, \\ Passage des Déportés 2, 5030 Gembloux, Belgium; jerome.bindelle@uliege.be \\ * Correspondence: adrien.michez@uliege.be
}

Received: 30 March 2020; Accepted: 19 May 2020; Published: 21 May 2020

check for updates

\begin{abstract}
Applied to grazing management, unmanned aerial systems (UASs) allow for the monitoring of vegetation at the level of each individual on the pasture while covering a significant area ( $>10$ ha per flight). Few studies have investigated the use of UASs to describe the forage quality in terms of nutritive value or chemical composition, while these parameters are essential in supporting the productive functions of animals and are known to change in space (i.e., sward species and structure) and time (i.e., sward phenology). Despite interest, these parameters are scarcely assessed by practitioners as they usually require important laboratory analyses. In this context, our study investigates the potential of off-the-shelf UAS systems in modeling essential parameters of pasture productivity in a precision livestock context: sward height, biomass, and forage quality. In order to develop a solution which is easily reproducible for the research community, we chose to avoid expensive solutions such as UAS LiDAR (light detection and ranging) or hyperspectral sensors, as well as comparing several UAS acquisition strategies (sensors and view angles). Despite their low cost, all tested strategies provide accurate height, biomass, and forage quality estimates of timothy pastures. Considering globally the three groups of parameters, the UAS strategy using the DJI Phantom 4 pro (Nadir view angle) provides the most satisfactory results. The UAS survey using the DJI Phantom 4 pro (Nadir view angle) provided $\mathrm{R}^{2}$ values of $0.48,0.72$, and 0.7 , respectively, for individual sward height measurements, mean sward height, and sward biomass. In terms of forage quality modeling, this UAS survey strategy provides $R^{2}$ values ranging from 0.33 (Acid Detergent Lignin) to 0.85 (fodder units for dairy and beef cattle and fermentable organic matter). Even if their performances are of lower order than state-of-art techniques such as LiDAR for sward height or hyperspectral sensors (for biomass and forage quality modeling), the important trade-off in terms of costs between UAS LiDAR $(>100,000 €)$ or hyperspectral sensors $(>50,000 €)$ promotes the use of such low-cost UAS solutions. This is particularly true for sward height modeling and biomass monitoring, where our low-cost solutions provide more accurate results than state-of-the-art field approaches, such as rising plate meters, with a broader extent and a finer spatial grain.
\end{abstract}

Keywords: unmanned aerial vehicles; unmanned aerial systems; drone; precision grazing; pasture biomass modeling; sward height; pasture height; forage quality; nutritive value 


\section{Introduction}

The management of pastures through direct grazing is not an easy task, as managers have to act on a complex system including the dynamic growth of multi-species grasslands in close interaction with animals which graze them selectively and non-homogeneously in time and space. The tools available to farmers for managing grazed pastures and adjusting forage demand to grass growth are still rather static (e.g., fences). Applied to grazing management, precision livestock farming promotes more dynamic management of ruminants on grasslands, at the level of each individual on the pasture. Over the past decade, research developments in sensors and information technology have opened up new monitoring approaches for grazing animals, especially cattle [1-4]. Such developments have allowed for the monitoring of grazing processes in space and time at the smallest possible level, namely, the individual bite [5]. This opens up the possibility for new management practices such as virtual fencing [6]. In addition to the monitoring of individual grazing animals, new developments in remote sensing allow for the characterization of grazed vegetation at similar to even finer spatial scales through the use of unmanned aerial systems (UASs). UASs can cover areas relevant to a grazing management perspective ( $>10$ ha per flight) while providing imagery at a very high spatial resolution $(<0.1 \mathrm{~m})$. Moreover, UASs are versatile tools which can be deployed on demand by the end-user to synchronize the acquisition of aerial imagery with the need for data on the field. As they fly at very low altitudes (generally $<100 \mathrm{~m}$ above ground level), they can collect data under more diverse weather conditions than other remote-sensing solutions, especially on cloudy days. In the context of environmental monitoring, UASs can be used for quantitative crop monitoring [7], weed detection [8], plant phenotyping [9], and early pest detection [10]. They have also been used for grazing applications in research, including the monitoring of biomass [11] and the detection of invasive weeds [12]. Thanks to their higher versatility, UASs can be used to acquire dense time-series $[13,14]$, which opens up new avenues in terms of vegetation phenology characterization. For example, UASs can be used for the characterization of organismic-level variability vegetation phenology in forests [15] or to identify different development stages and irrigation treatments in maize [16]. Moreover, UAS remote sensing can reveal small-scale heterogeneities which could usually only be revealed by in situ observation and missed by satellite remote sensing [17]. In terms of the imagery methods that are applied, UAS are commonly used to produce 3D data using structure from motion (SFM) photogrammetry and spectral information. SFM photogrammetry can be used to derive crop surface/height models from UAS imagery at very low costs compared to LiDAR (laser detection and ranging). Depending on the sensor used, the spectral information provided by a UAS can be simple RGB (red-green-blue) provided by an off-the-shelf camera or may be more specific when using multispectral, thermal, or even hyperspectral cameras [18].

In the context of precision grazing, UAS imagery can provide higher frequency, higher spatial resolution, and more precise information about the biomass productivity of a pasture. Pasture height information is of utmost importance for farmers; more critical than biomass, sward height is indeed the most critical parameter driving the instantaneous efficiency of forage intake from an animal's perspective [19]. Hence, grazing management methods aiming to maximize the short-term intake rate of animals must rely on the accurate monitoring of sward height, its spatial distribution, and its change over time. However, such measurements are still typically taken with low-frequency and time-consuming instruments, notably sward-sticks or rising plate meters [20]. The ability of UASs to describe the sward height and biomass has been well-documented in the literature (see, e.g., [21-25]). For the specific case of sward height, the methodological challenge can be addressed similarly to that in other disciplines related to vegetation characterization. The vegetation height is typically computed from a UAS photogrammetric digital surface model (DSM) combined with a digital terrain model (DTM). Such photogrammetric approaches can compete with strictly LiDAR approaches in various vegetation types (see, e.g., Michez et al. [26] in pasture, Yuan et al. [27] for wheat, and Lisein et al. [28] in forest). The data sources of the DTM are various, depending on the application. In the case of sward height, the DTM can be derived from a pre-existing LIDAR DTM [26,29], interpolated precision 
GNSS (Global Navigation Satellite Systems) points [30], or a UAS photogrammetric DSM based on imagery acquired when the ground is bare or the pasture is freshly mowed [25]. Fewer studies have undertaken the use of UASs to describe the forage quality mainly with hyperspectral sensors [31-33] or a combination of RGB or multispectral sensors [34,35]. This parameter is essential to support the productive functions of the animals once the forage has been consumed, and is known to change with species composition (i.e., in space) over the area of the pasture, and with the physiological development of forage plants over the grazing season (i.e., in time) [36]. Despite the interest of these parameters, they are typically scarcely assessed by practitioners, as their assessment requires important laboratory analyses. Hence, there is an important need for forage quality information at higher spatio-temporal resolution, which could be fulfilled by UASs.

In this context, we propose to investigate the potential of off-the-shelf UASs to model essential parameters of pasture productivity in a precision livestock farming context: sward height, biomass, and forage quality. In order to develop a solution which is easily reproducible for the research community, we chose to avoid expensive solutions, such as UAS LiDAR or hyperspectral sensors, and to focus on low-cost solutions. More specifically, our objectives are twofold:

(1) compare low-cost off-the-shelf UAS approaches (between 1000 and $5000 €$ ) to monitor essential components of grassland heterogeneity in a precision livestock context;

(2) provide practical recommendation for researchers and practitioners willing to develop precision grazing applications based on low-cost UASs.

\section{Materials and Methods}

\subsection{Study Area}

The study took place on the experimental farm of Michamps $\left(50^{\circ} 02^{\prime} 16.0^{\prime \prime} \mathrm{N} 5^{\circ} 48^{\prime} 28.4^{\prime \prime} \mathrm{E}\right)$, Wallonia, Southern Belgium, in the Ardenne ecoregion, where a field trial dedicated to timothy grass (Phleum pretense L.) was set up in spring 2017. The field trial was composed of eighty $7 \times 1.5 \mathrm{~m}$ plots (Figure 1). All 80 plots were seeded with different varieties of timothy and were largely dominated by timothy during the experiment. The mean sward height ( \pm standard deviation) was $0.76 \pm 0.18 \mathrm{~m}$ when the study was conducted, with a mean ( \pm standard deviation) dry above-ground biomass of $5494 \pm 929 \mathrm{~kg} / \mathrm{ha}$. The topography was rather homogeneous across the study site, with a mean ( \pm standard deviation) altitude of $498 \pm 1.6 \mathrm{~m}$.

\subsection{Acquisistion of Unmanned Aerial System Imagery}

In order to ease the replicability of our approach, our study focused on low-cost UASs which are among the most common found worldwide (the DJI Phantom 4 Pro and Mavic 2 Pro Platinum, Shenzen, China), as well as the use of a multispectral sensor (Parrot Sequoia, Paris, France) which has been widely established in the UAS community. The multispectral sensor was mounted with its sunshine sensor on the DJI P4 Pro, thanks to a 3D printed mount, and a $6700 \mathrm{mAh}$ powerbank for the power supply. Compared to the on-board RGB sensors (FC6310-P4Pro and FC220-Mavic Pro), the multispectral sensor had a lower spatial resolution $(1.2 \mathrm{Mpx})$ but provided fine multispectral information, covering green $(550 \mathrm{~nm})$, red $(660 \mathrm{~nm})$, near-infrared $(735 \mathrm{~nm})$, and red-edge $(790 \mathrm{~nm})$ wavelengths. The full width at half maximum was $40 \mathrm{~nm}$ for red, green, and near-infrared, and $10 \mathrm{~nm}$ for the red-edge wavelength.

The aerial images were acquired as close as possible to solar noon on the 6th of June, 2019, and were further processed and analyzed following five different UAS survey modalities (Table 1). Before each flight, a picture of a calibrated reflectance panel (see Figure 2) was taken, in order to further ensure the radiometric calibration of the multispectral imagery. The flight height was set to $30 \mathrm{~m}$ for all flight surveys listed in Table 1. The PixCapture Android application (PiX4D, Lausanne, Switzerland) was used on an android device, with high overlap and lowest possible speed set in the app menu. 
Table 1. The unmanned aerial system (UAS) survey strategies evaluated. For each reference, the associated mapping products describe the raster data used to predict pasture parameters. R: red; G: green; B: blue; NIR: near-infrared; RE: red-edge; GSD: ground sampling distance.

\begin{tabular}{|c|c|c|c|c|}
\hline Reference & Sensor & UAS & View Angle & UAS Mapping Product (GSD) \\
\hline Mavic NADIR & FC220 & $\begin{array}{l}\text { Mavic Pro } 2 \\
\text { platinum }\end{array}$ & Nadir & $\begin{array}{l}\text { Sward Height Model }(0.02 \mathrm{~m}) \\
\text { Orthophotomosaic RGB }(0.01 \mathrm{~m})\end{array}$ \\
\hline Sequoia NADIR & $\begin{array}{c}\text { Sequoia } \\
\text { multispectral }\end{array}$ & $\begin{array}{l}\text { Phantom } 4 \\
\text { Pro }\end{array}$ & Nadir & $\begin{array}{l}\text { Sward Height Model }(0.05 \mathrm{~m}) \\
\text { Orthophotomosaic R G NIR RE }(0.025 \mathrm{~m})\end{array}$ \\
\hline Phantom NADIR & FC6310 & $\begin{array}{l}\text { Phantom } 4 \\
\text { Pro }\end{array}$ & Nadir & $\begin{array}{l}\text { Sward Height Model }(0.02) \\
\text { Orthophotomosaic RGB }(0.01 \mathrm{~m})\end{array}$ \\
\hline $\begin{array}{l}\text { Phantom } \\
\text { OBLIQUE }\end{array}$ & FC6310 & $\begin{array}{l}\text { Phantom } 4 \\
\text { Pro }\end{array}$ & Oblique $\left(70^{\circ}\right)$ & $\begin{array}{l}\text { Sward Height Model }(0.02 \mathrm{~m}) \\
\text { Orthophotomosaic RGB }(0.01 \mathrm{~m})\end{array}$ \\
\hline Phantom MERGED & FC6310 & $\begin{array}{l}\text { Phantom } 4 \\
\text { Pro }\end{array}$ & Nadir & $\begin{array}{l}\text { Sward Height Model }(0.02 \mathrm{~m}) \\
\text { Orthophotomosaic RGB }(0.01 \mathrm{~m})\end{array}$ \\
\hline
\end{tabular}
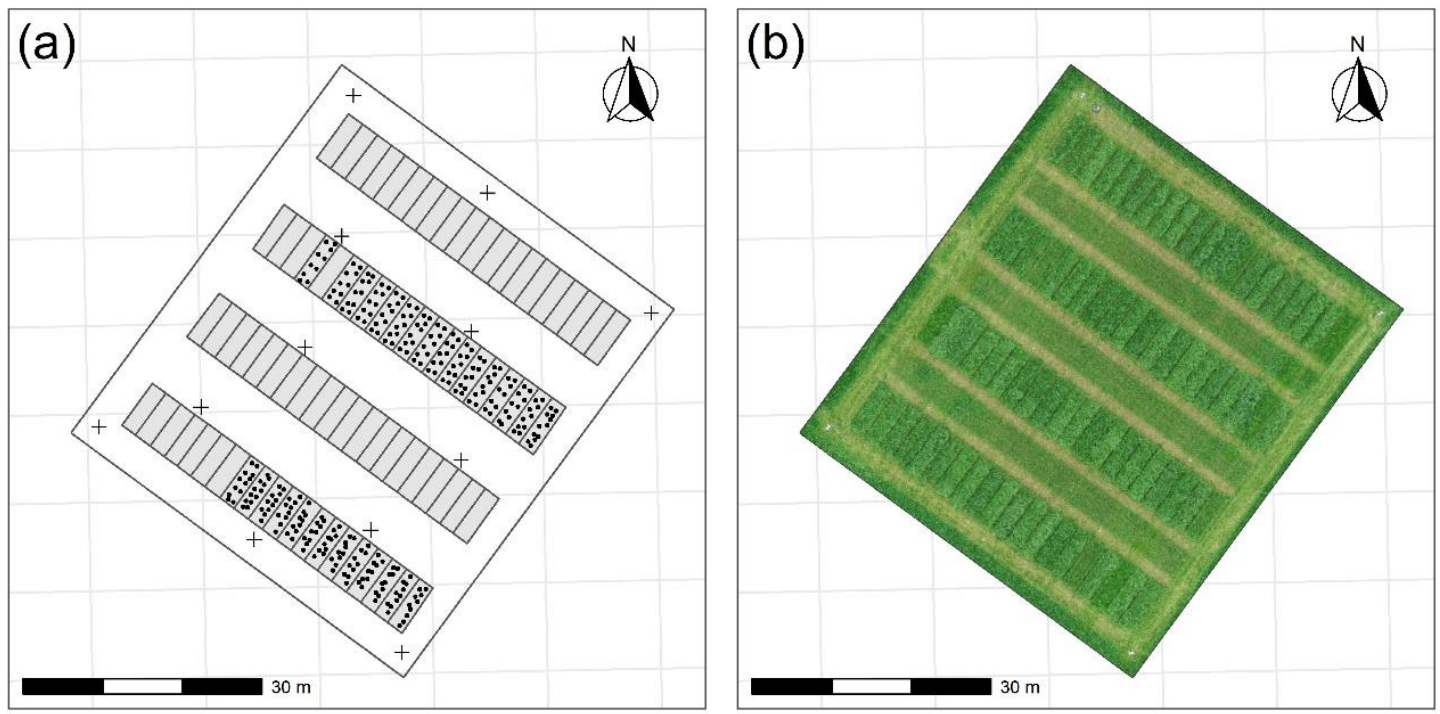

Figure 1. Study site composed of 4 lines of 20 plots $\left(10.5 \mathrm{~m}^{2}\right.$;). Left panel (a)ground control points $(+, 12)$ evenly distributed across the site. Sward height measurements $(\cdot, 296)$ were realized in 29 plots in two separate lines. Right panel (b): RGB orthophotomosaic from DJI Mavic pro 2 Platinum $(1 \mathrm{~cm}$ ground resolution).

(a)

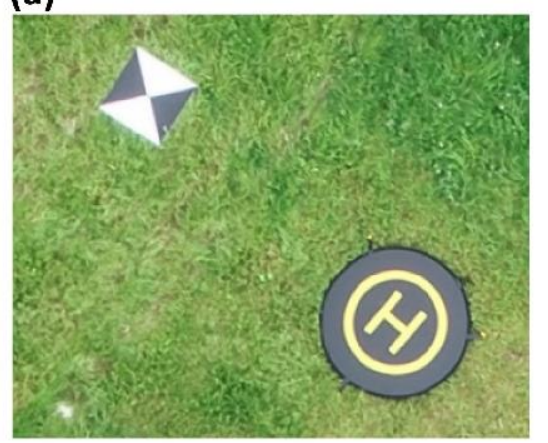

(b)

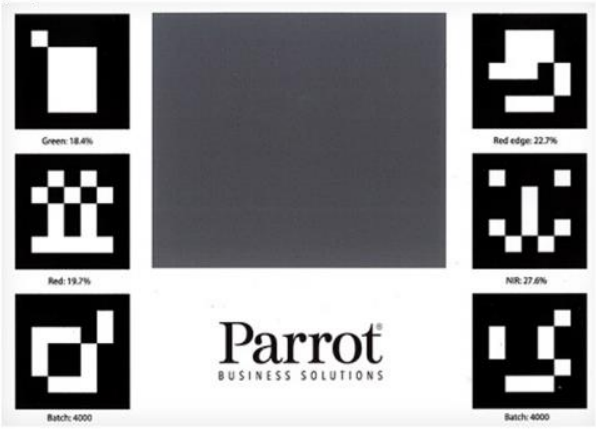

Figure 2. The left panel (a) is a zoom onto the RGB orthophotomosaic from DJI Mavic pro 2 Platinum (1 $\mathrm{cm}$ ground resolution) centered on a ground control point (GCP; $0.5 \mathrm{~m}$ plastic square), used to ensure geometric calibration, as well as the take-off and landing device. The black and white pattern of the GCP allows for automatic location by the photogrammetric software used in the study. The right pannel (b) represents the white balance card used to perform radiometric calibration. 
Twelve ground control points (GCPs) consisting of black and white square plastic boards were evenly spread across the surveyed area to ensure proper geometric calibration (Figures 1 and 2). The GCPs were precisely georeferenced (XYZ accuracy $<1 \mathrm{~cm}$ ) with an Emlid Reach (Emlid Ltd., Hong Kong) RS+ GNSS (Global Navigation Satellite System) receiver using Real Time Kinematic and corrections provided by the local CORS (Continuously Operating Reference Station) network.

\subsection{Processing of Unmanned Aerial System Imagery}

All UAS imagery was processed with the Agisoft Metashape 1.5.5 software, from photogrammetric reconstruction to the spectral calibration. Agisoft Metashape has been widely used in the UAS scientific community to reconstruct high-resolution and reliable 3D models from UAS surveys (see, e.g., [37-39]). The image alignment step was realized in full resolution ("High" accuracy parameter in Agisoft), while limiting the number of points to be matched at 40,000 points per image as well as a maximum of 4000 points per image after the matching steps (respectively, "Key points limit" and "Tie point limit" in Agisoft). The geometrical quality of the 3D models was optimized on the basis of the GCP network. Following the recommendations of James et al. [37] to avoid potential overfitting, the following parameters were kept fixed during the optimization process: affinity and skew transformation coefficients (b1 and b2 in Agisoft), and additional tangential and radial distortion coefficients ( $\mathrm{k} 4$ and p3/p4 in Agisoft). As the FC220 sensor of the Mavic Pro camera uses an electronic shutter, we applied a specific calibration strategy to avoid the excessive reconstruction errors inherent to such cameras [40] ("Enable rolling shutter compensation" activated in the Agisoft optimization process).

The depth map generation processing was realized on aggregated UAS imagery (aggregation factor of 2), in order to reduce the total number of pixels by images by 4 -fold, optimizing the processing time and reducing potential noise ("Aggressive" depth filtering strategy and "High" level of accuracy in Agisoft). The orthomosaic process was performed with the digital elevation model (interpolation enabled) as the reference surface, using the "Average" blending mode strategy. For the radiometric calibration of the multispectral camera, we followed the workflow recommended by Agisoft, which integrates the use of a calibrated reflectance panel and the information provided by the sunshine sensor. In terms of spectral information, the photogrammetric processing resulted in RGB orthomosaics for the on-board RGB sensors and a reflectance orthomosaic for the embarked Parrot Sequoia multispectral sensor, as listed in Table 1.

Sward height models were computed by subtracting a LiDAR digital terrain model (DTM) from the high spatial resolution photogrammetric DEM, in order to provide a raster of the sward height. The spatial resolution of the sward height models ranged from 0.02 to $0.05 \mathrm{~m}$, depending on the sensor used to perform the photogrammetric DEM (Table 1). The LiDAR DTM (1 m GSD) was acquired by public regional administration. The study site was surveyed in February 2014.

\subsection{Sward Height Reference Data}

Sward height was assessed immediately after the UAS image surveys in 29 different plots, providing a total of 296 sward height measurements (Figure 1). A minimum of 10 measurements were carried out in each plot, in order to capture the structural heterogeneity. Sward height measurement was carried out using a ruler tape unrolled on the pole of an Emlid Reach RS+ GNSS. The sward height recorded was the height of the first blade of grass within a $5 \mathrm{~cm}$ wide torus around the GNSS pole. Each sward height measurement was precisely geo-localized (centimetric accuracy) using Real Time Kinematic and corrections provided by the local CORS network. At the plot scale, the sward height was aggregated by mean for further comparison with UAS imagery.

\subsection{Biomass and Forage Quality Data}

The study area was harvested on the 7th of June, 2019. During the harvest process, the entire plot's fresh material was weighed using a Haldrup harvester (Haldrup, Ilshofen, Germany) and fresh material was collected throughout the harvest process. Samples were then dried at $60^{\circ} \mathrm{C}$ and weighed before 
being analyzed by means of near-infrared reflectance spectroscopy (NIRS) using a reference database from the regional reference laboratory network (Requasud, Gembloux, Belgium). The NIRS estimates were considered reliable, as the Mahalanobis distance between the spectra of the samples and those in the NIRS calibration database (measured using standard wet chemistry reference methods) were low. The following forage chemical composition parameters were assessed: dry matter content (DM), crude ash, crude protein (nitrogen $\times 6.25$ ), crude cellulose, neutral detergent fiber, acid detergent fiber, and acid detergent lignin. In addition, several nutritive value parameters for cattle were determined: in vitro DM digestibility (De Boever's method), digestible organic matter, fermentable organic matter, digestible protein, fodder unit for dairy and beef cattle (French "unités fourragères lait" and "unités fourragères viande", UFL and UFV), intestinal digestible protein allowed by energy and nitrogen content of the forage (French "protéines digestibles dans l'intestin", PDIE and PDIN), and rumen protein balance (Dutch "onbestendig eiwit balans", OEB).

\subsection{Modeling the Height, Biomass, and Forage Quality}

We used single and multiple linear regression (MLR) modeling to model sward height as well as pasture biomass and forage quality with UAS imagery. The same modeling approach was tested for the five different UAS survey strategies, in order to compare the different sensor types and configurations (i.e., close to nadir angle and oblique imagery), and to provide practical recommendations to the UAS research community.

The UAS spectral imagery was synthetized using the vegetation indices (VIs) listed in Table 2 for RGB sensors (Mavic and Phantom Pro on-board cameras) and in Table 3 for the multispectral imagery (Parrot Sequoia). The choice of these VIs was made by considering their use in the existing literature, as well as their ability to cover the full spectral ranges of the selected sensors. In terms of UAS 3D variables, we used the mean sward height value as well as the coefficient of variation (standard deviation / mean) of the UAS height, in order to take into account the heterogeneity of the UAS sward height for the considered plots. The main goal of our approach was to test the modeling capacity of the different UAS survey strategies, in order to provide practical recommendations for the research community. We did not investigate the individual contributions of the different predictors, in order to ease the reading. In an analogous manner, the potential collinearity among UAS parameters was not assessed, as the individual contributions of the UAS parameters were not addressed in the study.

Table 2. Vegetation indices computed from the RGB imagery (FC220 for Mavic and FC6310 for Phantom 4). R: red; G: green; B: blue. Each layer was divided by the associated brightness (i.e., the mean value of all bands).

\begin{tabular}{ccc}
\hline Vegetation Index & Formula & Reference \\
\hline Green Red Difference Index (GRDI) & $\frac{(\mathrm{G}-\mathrm{R})}{(\mathrm{G}+\mathrm{R})}$ & {$[41]$} \\
\hline $\begin{array}{c}\text { Modified Green Red Vegetation Index (MGRVI) } \\
\text { Red Green Blue Vegetation Index (RGBVI) }\end{array}$ & $\frac{\left(\mathrm{G}^{2}-\mathrm{R}^{2}\right)}{\left(\mathrm{G}^{2}+\mathrm{R}^{2}\right)}$ & {$[25]$} \\
\hline $\begin{array}{c}\left(\mathrm{R}^{2}-(\mathrm{B} * \mathrm{R})\right) \\
\left(\mathrm{R}^{2}+(\mathrm{B} * \mathrm{R})\right)\end{array}$ & {$[25]$} \\
\hline $\begin{array}{c}\text { Normalized Green Blue Index (NGBI) or Plant } \\
\text { Normalized Red Blue Index (NRBI) }\end{array}$ & $\frac{(\mathrm{G}-\mathrm{B})}{(\mathrm{G}+\mathrm{B})}$ & {$[42]$} \\
\hline Visible Atmospherically Resistant Index (VARI) & $\frac{(\mathrm{R}-\mathrm{B})}{(\mathrm{R}+\mathrm{B})}$ & {$[13]$} \\
\hline
\end{tabular}


Table 3. Vegetation indices computed from the reflectance layers provided by the multispectral camera. R: red; G: green; NIR: near-infrared; RE: red-edge.

\begin{tabular}{ccc}
\hline Vegetation Index & Formula & Reference \\
\hline Normalized Difference Vegetation Index (NDVI) & $\frac{(\mathrm{NIR}-\mathrm{R})}{(\mathrm{NIR}+\mathrm{R})}$ & {$[45]$} \\
\hline Normalized Difference Red Edge (NDRE) & $\frac{(\mathrm{NIR}-\mathrm{RE})}{(\mathrm{NIR}+\mathrm{RE})}$ & {$[46]$} \\
\hline Green NDVI (GNDVI) & $\frac{(\mathrm{NIR}-\mathrm{G})}{(\mathrm{NIR}+\mathrm{G})}$ & {$[47]$} \\
\hline Green Ratio Vegetation Index (GRVI) & $\frac{\mathrm{NIR}}{\mathrm{G}}$ & {$[48]$} \\
\hline Chlorophyll Vegetation Index (CVI) & $\mathrm{NIR} * \frac{\mathrm{R}}{\mathrm{G}^{2}}$ & {$[49]$} \\
\hline Chlorophyll Index Red-edge (CIR) & $\frac{\mathrm{NIR}}{\mathrm{RE}}-1$ & {$[49]$} \\
\hline Normalized Green-Red Difference Index & $\frac{(\mathrm{G}-\mathrm{R})}{(\mathrm{G}+\mathrm{R})}$ & {$[41]$} \\
\hline Red Ratio Vegetation Index (RVI) & $\frac{\mathrm{NIR}}{\mathrm{R}}$ & {$[50]$} \\
\hline
\end{tabular}

The sward height was modeled at two spatial scales: the individual sward height measurement (Model 1) and the plot (Model 2). At the individual sward height measurement, the height value provided by the associated UAS sward height model at the direct location of the field sward height measurement was retained. At the plot scale, the mean field sward height was modelled with the mean UAS sward height. Models 1 and 2 were fitted recursively for each UAS survey strategy. At each step, the adjusted $\mathrm{R}^{2}$ value was kept as a model performance indicator, as well as the root mean square error (RMSE).

Model 1:

$$
\text { Sward }_{\text {heightfield }}=\mathrm{f}\left(\text { Sward }_{\text {heightUAS }}\right)
$$

Model 2:

$$
\overline{\text { Sward }_{\text {heightfield }}}=\mathrm{f}\left(\overline{\text { Sward }_{\text {heightUAS }}}\right)
$$

Above-ground biomass (on a dry-matter basis, Model 3) and forage quality (Model 4) were fitted using an MLR approach, in order to link both spectral and 3D information provided by UAS imagery. Models 3 and 4 were fitted recursively for each UAS survey strategy. At each iteration step, the adjusted $\mathrm{R}^{2}$ value was kept as a model performance indicator, as well as the root mean square error (RMSE). For modeling of forage quality (chemical composition and nutritive value; Model 4), the process was repeated for each parameter.

Model 3:

$$
\mathrm{AGB}=\mathrm{f}\left(\mathrm{VI}_{\mathrm{UAS}}, 3 \mathrm{D}_{\mathrm{UAS}}\right)
$$

Model 4:

$$
\begin{aligned}
& \text { Forrage }_{\text {quality }_{1}}=\mathrm{f}\left(\mathrm{VI}_{\mathrm{UAS}}, 3 \mathrm{D}_{\mathrm{UAS}}\right) \\
& \text { Forrage }_{\text {quality }_{2}}=\mathrm{f}\left(\mathrm{VI}_{\mathrm{UAS}}, 3 \mathrm{D}_{\mathrm{UAS}}\right)
\end{aligned}
$$

\section{Results}

\subsection{Sward Height Modeling with UAS}

The sward height estimates provided by the UAS were in good agreement with the field-measured sward height, as displayed in Figure 3. Similar model performance for Model 1 (individual sward heights) was found across the five different UAS survey strategies. The $\mathrm{R}^{2}$ values ranged from 0.46 to 0.49 , with relative RMSE (rRMSE) values at 19\%. In terms of mean signed error (field height - UAS height), all UAS survey strategies were associated with positive mean values, highlighting a trend of UAS sward height model to underestimate the sward height measured on the ground. The UAS 
estimates provided by the DJI Phantom 4 presented lower mean signed error values: 0.07, 0.07, and 0.08 for "Phantom Nadir", "Phantom Oblique", and "Phantom Merged", respectively.

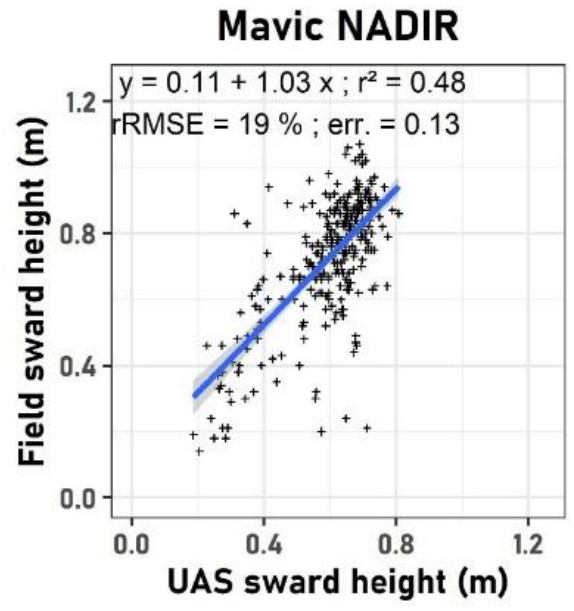

Phantom NADIR

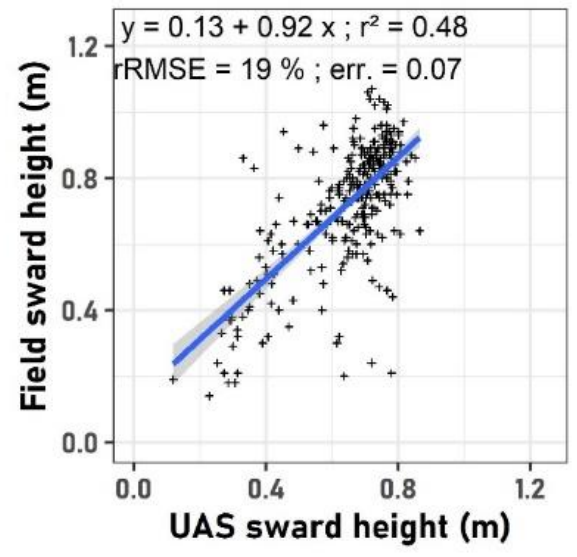

Phantom MERGED

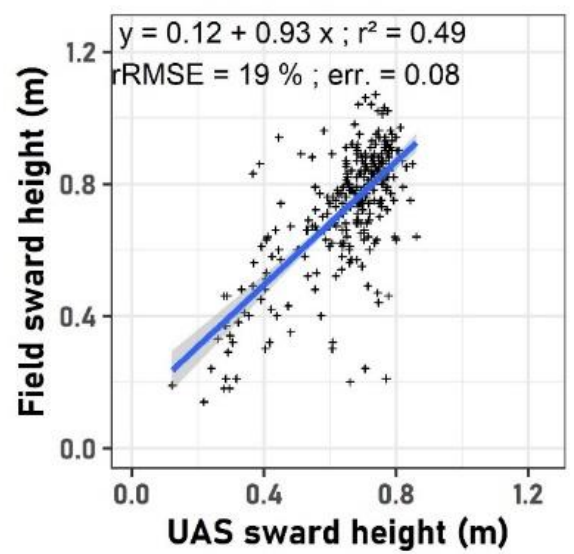

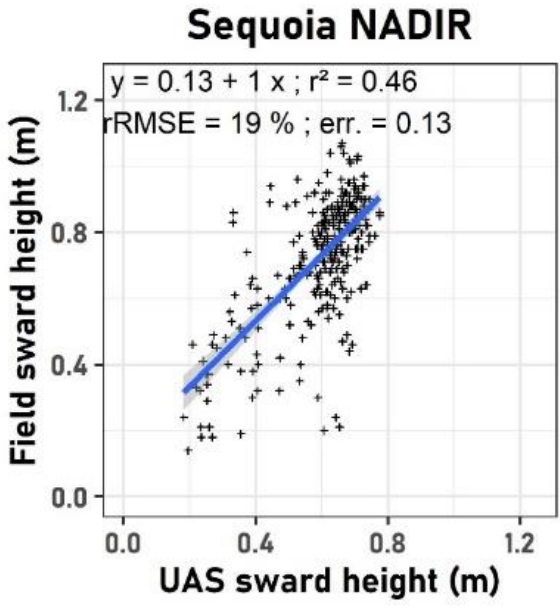

Phantom OBLIQUE

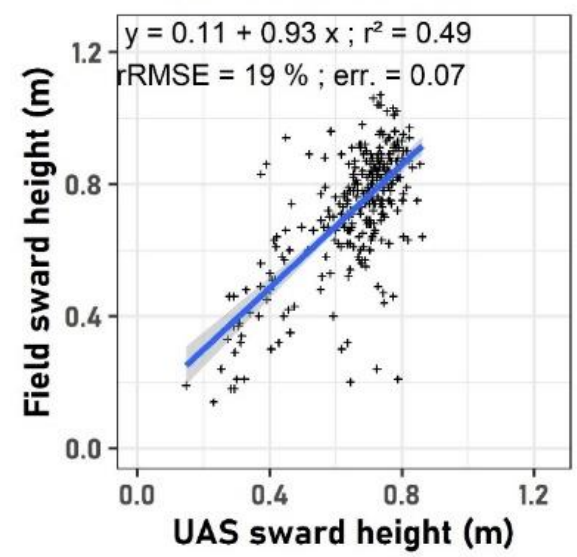

Figure 3. Biplots of sward height from UAS sward height model and from field measurements. The mean error (err.) is computed from the difference between the reference field sward height and the UAS sward height. Relative root mean square error (rRMSE) is computed from the RMSE ratio with the mean field sward height measurements. The blue line is the regression line fitted over the plotted data (Model 1). The grey area around the regression line represents the $95 \%$ confidence region.

When averaged at the plot scale $\left(10.5 \mathrm{~m}^{2}\right)$, the UAS sward height estimates presented a better agreement with the field sward height averaged at the same plot scale (Figure 4). In terms of model 
performance, the trends were similar at the plot (Model 2) and the individual (Model 1) measurement scales (Figures 3 and 4). Indeed, all UAS survey strategies presented comparable $\mathrm{R}^{2}$ values (0.71-0.73) and rRMSE values (9\%-10\%), while the UAS survey strategies using images from Phantom 4 presented lower mean error (field height - UAS height) values. The same trend of underestimating the field sward height was also highlighted at the plot scale.

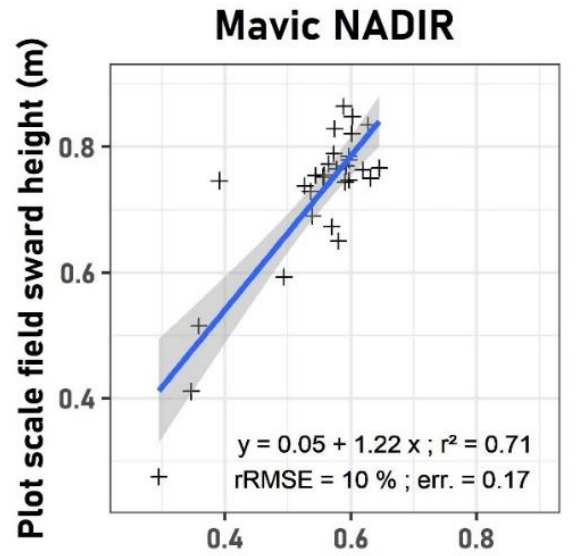

Plot scale UAS sward height $(\mathrm{m})$ Phantom NADIR

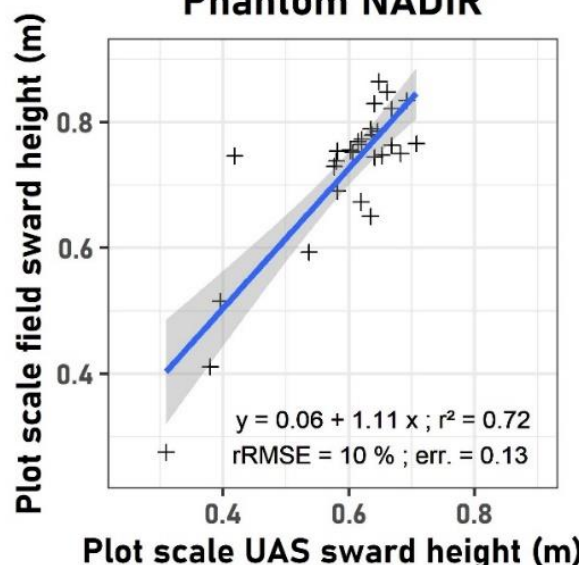

Phantom MERGED

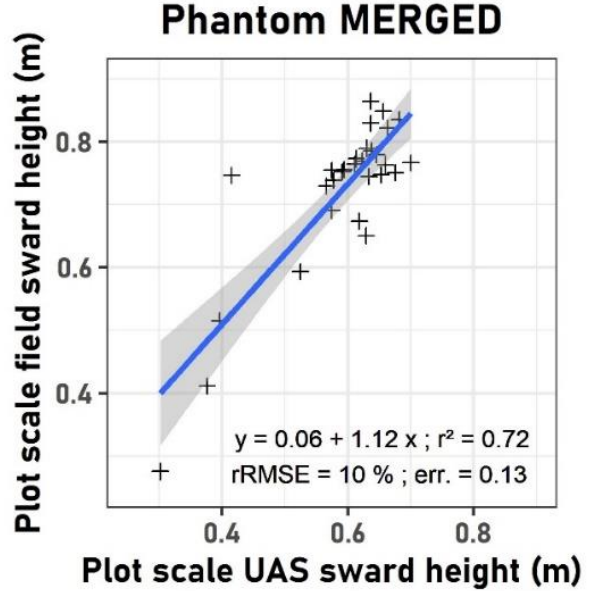

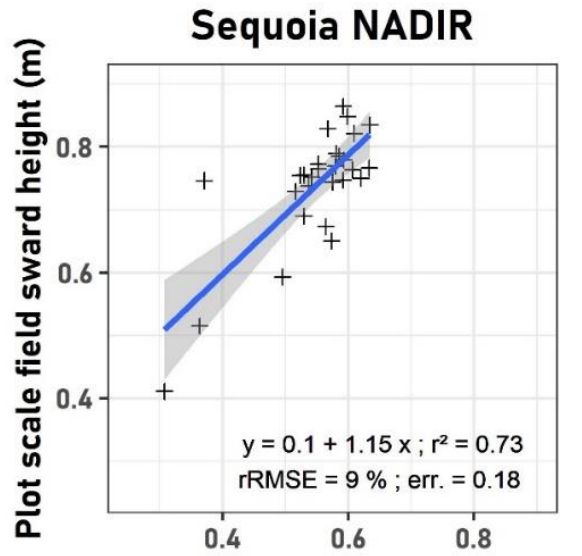

Plot scale UAS sward height (m)

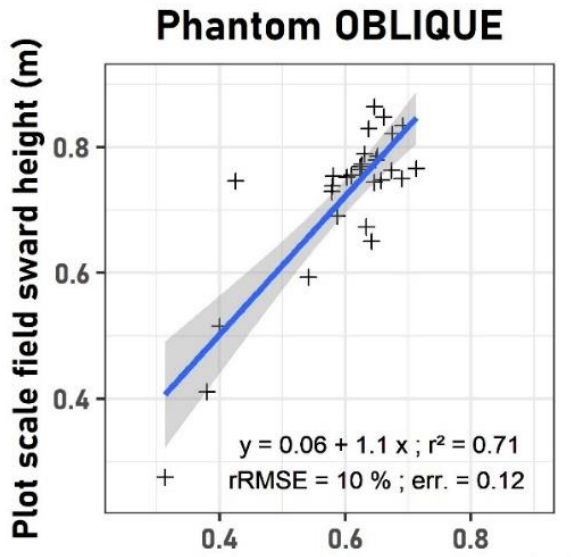

Plot scale UAS sward height $(\mathrm{m})$

Figure 4. Biplots of the mean UAS sward height and field measurements. The mean error (err.) is computed from the difference between the reference mean field sward height and the mean UAS sward height. Relative root mean square error (rRMSE) is computed from the RMSE ratio with the mean of the mean plot sward height measurements. The blue line is the regression line. The grey area around the regression line represents the $95 \%$ confidence region. 


\subsection{Above-Ground Biomass Modeling with UAS}

From the multiple linear regression (MLR) modeling of the dry above-ground biomass (AGB, Model 3), as highlighted in Figure 5, similar model performance was seen across the UAS survey strategies. Nevertheless, the Sequoia Nadir UAS survey strategy presented the best performance, with the lowest rRMSE (9\%) and highest $R^{2}$ value (0.74).
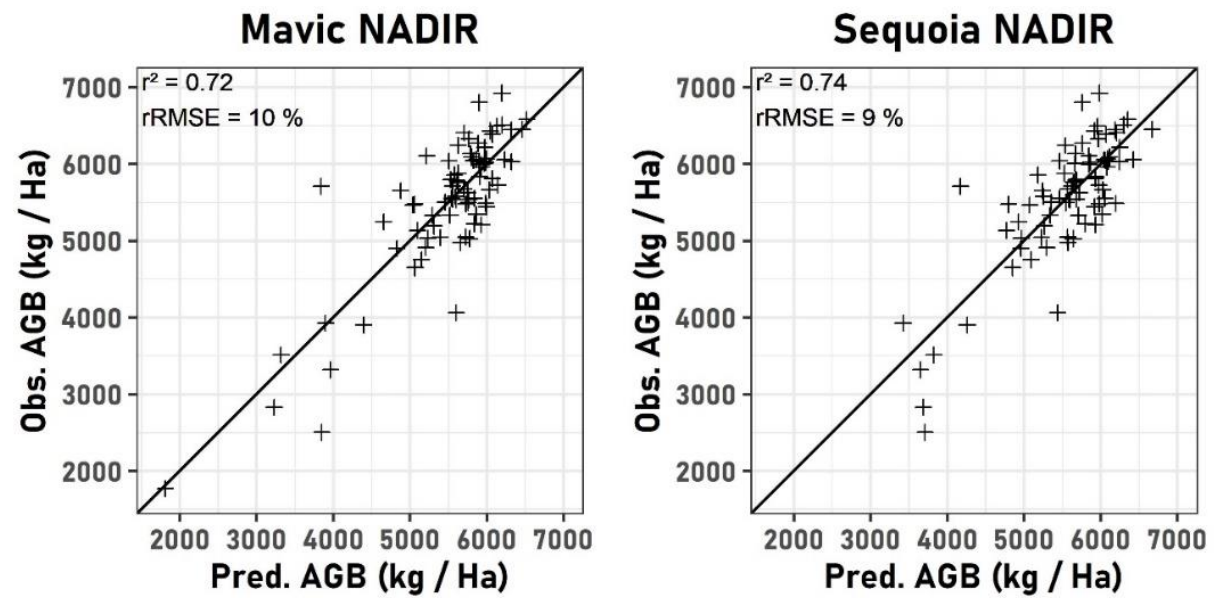

Phantom NADIR
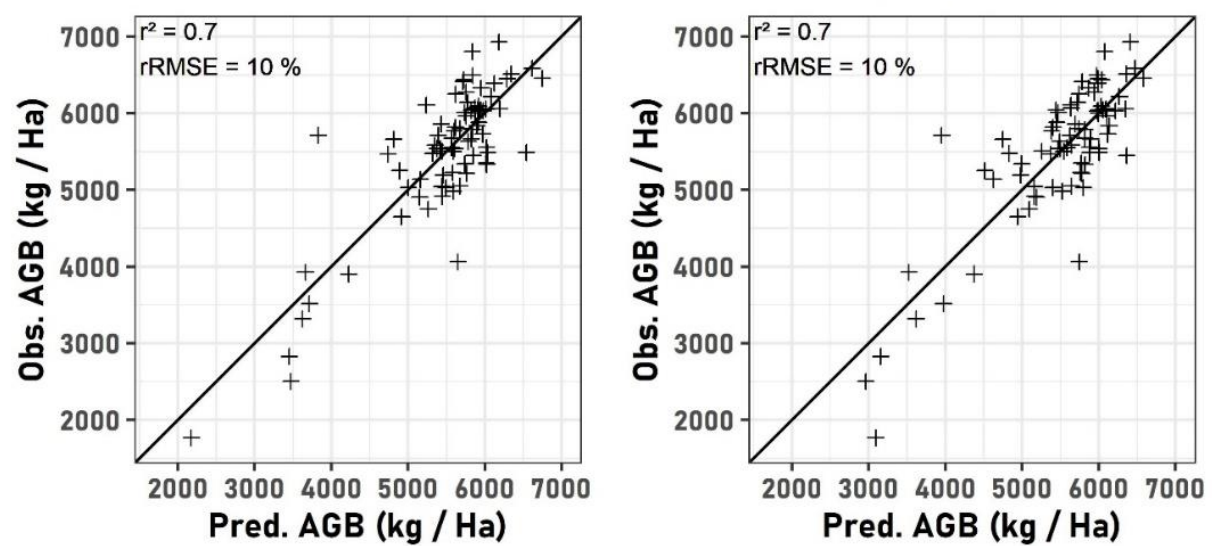

Phantom MERGED

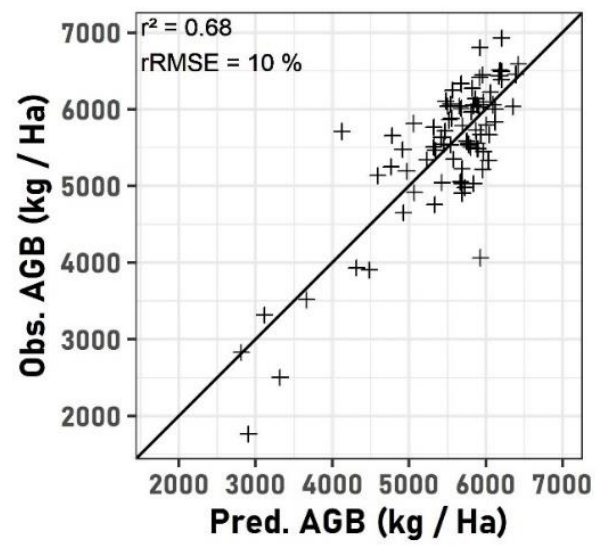

Figure 5. Modeling dry above-ground biomass (AGB) using five different UAS survey strategies (Model 3). The solid lines represent the 1:1 lines (i.e., $x=y$ ). Relative root mean square error (rRMSE) is computed from the RMSE ratio with the mean of reference AGB measurements. 


\subsection{Forrage Quality Modeling with UAS}

UAS imagery, whatever the survey strategy presented, satisfied forage quality modeling capabilities for most of the forage quality parameters (Table 4). The RGB UAS imagery reached similar performance results as the multispectral (Sequoia Nadir) survey strategy and even clearly outperformed the multispectral system in some aspects (i.e., for volatile protein balance, digestible protein, crude protein, intestinal digestible protein, bottom ashes, or dry matter rate). In the case of the "Phantom Nadir" survey strategy, it (sometimes slightly) outperformed the multispectral strategy for all parameters (except for the cellulose content). The "Phantom Nadir" strategy provided the best results for 12 parameters among 17 . For this strategy, the $\mathrm{R}^{2}$ values ranged from 0.33 (Acid Detergent Lignin) to 0.85 (fodder units for dairy and beef cattle and fermentable organic matter).

Table 4. Modeling the forage quality using five different UAS survey strategies. For each parameter, the best model's accuracy values are italicized.

\begin{tabular}{|c|c|c|c|c|c|c|c|c|c|c|}
\hline \multirow{2}{*}{ Parameters } & \multicolumn{2}{|c|}{ Sequoia Nadir } & \multicolumn{2}{|c|}{ Mavic Nadir } & \multicolumn{2}{|c|}{ P4 Merged } & \multicolumn{2}{|c|}{ P4 Nadir } & \multicolumn{2}{|c|}{ P4 Oblique } \\
\hline & $\mathbf{R}^{2}$ & RMSE & $\mathbf{R}^{2}$ & RMSE & $\mathbf{R}^{2}$ & RMSE & $\mathbf{R}^{2}$ & RMSE & $\mathbf{R}^{2}$ & RMSE \\
\hline \multicolumn{11}{|c|}{ Chemical composition } \\
\hline Dry matter (\%) & 0.07 & 1.19 & 0.17 & 1.13 & 0.33 & 1.01 & 0.47 & 0.9 & 0.25 & 1.07 \\
\hline Crude ash (\%) & 0.23 & 0.53 & 0.3 & 0.5 & 0.34 & 0.49 & 0.48 & 0.43 & 0.29 & 0.5 \\
\hline Crude protein (\%) & 0.24 & 1.06 & 0.18 & 1.1 & 0.42 & 0.93 & 0.54 & 0.82 & 0.4 & 0.93 \\
\hline Crude cellulose (\%) & 0.84 & 1.25 & 0.8 & 1.43 & 0.82 & 1.33 & 0.84 & 1.27 & 0.84 & 1.27 \\
\hline Neutral detergent fiber (\%) & 0.83 & 1.77 & 0.73 & 2.24 & 0.83 & 1.81 & 0.82 & 1.83 & 0.84 & 1.75 \\
\hline Acid Detergent Fiber (\%) & 0.79 & 1.34 & 0.68 & 1.66 & 0.8 & 1.31 & 0.77 & 1.4 & 0.82 & 1.24 \\
\hline Acid Detergent Lignin (\%) & 0.51 & 0.41 & 0.36 & 0.47 & 0.53 & 0.4 & 0.33 & 0.48 & 0.6 & 0.37 \\
\hline \multicolumn{11}{|c|}{ Nutritive value } \\
\hline $\begin{array}{c}\text { In-vitro DM digestibility } \\
(\%)\end{array}$ & 0.82 & 2.33 & 0.75 & 2.72 & 0.81 & 2.39 & 0.83 & 2.24 & 0.8 & 2.43 \\
\hline $\begin{array}{l}\text { Fermentable organic matter } \\
(\mathrm{g} / \mathrm{kg})\end{array}$ & 0.82 & 12.51 & 0.71 & 15.93 & 0.82 & 12.44 & 0.85 & 11.6 & 0.82 & 12.46 \\
\hline $\begin{array}{l}\text { Digestible organic matter } \\
\qquad(\mathrm{g} / \mathrm{kg})\end{array}$ & 0.82 & 12.81 & 0.74 & 15.52 & 0.81 & 13.06 & 0.84 & 12.19 & 0.81 & 13.1 \\
\hline Digestible protein (\%) & 0.24 & 10.31 & 0.18 & 10.67 & 0.42 & 9.01 & 0.54 & 7.99 & 0.41 & 9.1 \\
\hline PDI (g/kg) & 0.67 & 3.77 & 0.68 & 3.73 & 0.68 & 3.7 & 0.74 & 3.39 & 0.68 & 3.74 \\
\hline PDI-E (g/kg) & 0.42 & 3.91 & 0.44 & 3.86 & 0.51 & 3.59 & 0.61 & 3.22 & 0.51 & 3.62 \\
\hline PDI-N (g/kg) & 0.24 & 8.58 & 0.18 & 8.89 & 0.42 & 7.51 & 0.54 & 6.67 & 0.4 & 7.58 \\
\hline OEB (g/kg) & 0.29 & 7.59 & 0.12 & 8.45 & 0.49 & 6.4 & 0.6 & 5.65 & 0.48 & 6.46 \\
\hline $\begin{array}{l}\text { Fodder units for dairy } \\
\text { cattle (UFL/kg) }\end{array}$ & 0.83 & 0.02 & 0.74 & 0.03 & 0.82 & 0.02 & 0.85 & 0.02 & 0.82 & 0.02 \\
\hline $\begin{array}{l}\text { Fodder units for beef cattle } \\
\text { (UFV/kg) }\end{array}$ & 0.83 & 0.02 & 0.74 & 0.03 & 0.83 & 0.03 & 0.85 & 0.02 & 0.82 & 0.03 \\
\hline
\end{tabular}

\section{Discussion}

In terms of individual sward height modeling (Model 1, Figure 3), comparison with other studies is quite complex, as most studies have compared UAS sward averaged at a higher scale (e.g., Rueda-Ayala et al. [51], which evaluated the UAS sward height at the scale of $1 \mathrm{~m}^{2}$; plots) or compared UAS height to other height metrics such as grass length [26] or compressed grass height using rising plate meter [24] and drop disk approaches [22]. These two latter approaches allowed for higher model accuracy ( $R^{2}$ values of 0.86 and 0.70, respectively, for [24] and [22]), similar to those found in our study at plot scale (Model 2, Figure 4). These positive results confirm the potential of UAS to quickly and accurately describe grassland heterogeneity. Sward height models were computed by subtracting 
a LiDAR DTM from the high spatial resolution photogrammetric DEM. Even if the availability of aerial LiDAR surveys for entire regions/countries is still rare in most parts of the world, the use of pre-existing LiDAR DTM should be promoted, as it implies no additional field work to build the UAS sward height model and, thus, increases the operationality of UAS solutions. Nevertheless, attention must be paid to the potential errors relative to the LiDAR DTM itself, which mainly relies on ground point density and terrain complexity [52]. When a quality LiDAR DTM is not available, alternative strategies can be implemented rather easily. For example, a reference digital terrain model can be easily generated using a UAS survey performed when the field ground is bare or right after mowing of the studied pastures [25], as well as using interpolated precision GNSS point surveys [30]. While the aforementioned solutions do require extra field work, they can be performed using the same equipment (UAS and precision GNSS), preserving the applicability of the proposed approach. Three-dimensional modeling and mapping best practices generally advise the use of global shutter sensors and avoidance of low focal length (i.e., fisheye) cameras [53,54]. Not surprisingly, UAS strategies using the Phantom 4 on-board RGB sensor equipped with a mechanical global shutter and an $8.8 \mathrm{~mm}$ focal length performed the best, in terms of sward height modeling (Figures 3 and 4), regardless of scale considered (individual or plot scale). Nevertheless, despite the fisheye focal length $(4 \mathrm{~mm})$ of the Sequoia multispectral sensor and the rolling shutter of the Mavic on-board RGB sensors, the sward height models associated with these sensors obtained comparable results to those using the higher-quality on-board RGB sensor of the Phantom 4. UAS survey strategies using the Sequoia multispectral sensor and the RGB sensor from the DJI Mavic Pro can, therefore, provide satisfactory results in terms of sward height modeling at the individual field height measurement $\left(R^{2}=0.46\right.$ and 0.48 for Sequoia and Mavic, respectively), as well as at the $10.5 \mathrm{~m}^{2}$; plot scale $\left(\mathrm{R}^{2}=0.73\right.$ and 0.71 , respectively). Authors in other disciplines have also obtained satisfactory results using rolling shutter and fisheye lens cameras [40,54,55]. Recent improvements in most commercial photogrammetric suites (e.g., PiX4D and Agisoft) have included integrated specific calibration routines for rolling shutter sensors and fisheye lenses. This factor, in addition to the even and dense GCP network used in our study, contributed to the good quality of the sward height model based on a rolling shutter camera (FC220 from Mavic Pro 2) or a fisheye lens camera (Parrot Sequoia).

In terms of biomass modeling using UAS imagery, the results found in the literature are quite diverse and not easy to compare among each other, as they greatly vary depending on the type of grassland monitored as well as the sensor (e.g., RGB, multispectral, or hyperspectral) and the use of 3D data. Our biomass model (Model 4) reached ca. $0.7 \mathrm{R}^{2}$ values while combining VI and sward height information. These results are similar and even better than those obtained in most comparable studies in the literature. The important heterogeneity of the experimental study site can be a source of explanation for this. Our results were similar than those found by Lee et al. [11] $\left(R^{2}=0.77\right)$ on a multi-site dataset in Korea, Batistoti et al. [30] in tropical Brazilian savanna $\left(R^{2}=0.74\right)$, and Insua et al. [23] in Northern America $\left(\mathrm{R}^{2}=0.8\right)$. Some authors have found lower values [26,51] in less contrasting study sites in temperate European contexts. As highlighted by Grüner el al. [21], the species composition of the modeled pastures has a significant impact. They highlighted better model performance for clover-based pastures $\left(R^{2}=0.75\right)$ than for alfalfa-grass mixtures $\left(R^{2}=0.64\right)$. In our case, the low species diversity in our experimental site (timothy-dominated pastures) probably improved the biomass modeling process, as well as the use of sward height data. Nevertheless, our result did not reach the outstanding performances of Viljanen et al. [56] $\left(\mathrm{R}^{2}=0.96\right)$ using machine learning modeling approaches in Finland in a similar species context (timothy grass/meadow fescue). As for the sward height modeling, all UAS strategies presented similar performances for biomass modeling, highlighting the interest of UAS strategies using a low-cost platform like the DJI Mavic Pro. The potential of RGB approaches has also been highlighted by Lussem et al. [57], who reached similar performance $\left(\mathrm{R}^{2}=0.7\right)$ in biomass modeling using RGB or multispectral VIs. Näsi et al. [58] also highlighted that, for biomass modeling, RGB can provide quality results; however, it was still lower than the performance reached by hyperspectral sensors. Our results confirmed that UAS approaches 
can reach similar or even better ABG biomass modeling accuracy as that reached by state-of-the-art tools like rising plate meters $\left(R^{2}=0.72\right.$ for lucerne in Czech Republic [59], $R^{2}=0.31$ in various sites of the USA [60]), while potentially covering the entire study area with a very high spatial resolution.

Our results highlight the ability of UAS RGB imagery and multispectral imagery to predict forage quality heterogeneity (Table 4). To our knowledge, only a few recent studies have investigated to potential of UAS using low-cost RGB or multispectral cameras to predict forage quality parameters [34,35]. These authors analyzed similar forage quality parameters, such as the crude protein, acid, and neutral detergent fiber, and in-vitro digestibility. Our study successfully extended the forage quality parameters to energetic parameters like quantitative parameters (e.g., ash or dry matter), as well as energetic fodder units (for dairy/meat breeds). In the literature, most studies investigating such broad forage quality parameters have used hyperspectral sensors [31-33]. Even if hyperspectral UAS approaches outperform RGB or even multispectral approaches, the tradeoff in terms of cost is important to consider, as hyperspectral sensors generally exceed 50,000€. For comparison, a DJI Mavic cost around $1000 €$ and the Phantom 4 Pro $1500 €$ (+3500€ for the Parrot Sequoia) at the time that this manuscript was written.

The different linear regression models of pasture characteristics cannot be directly reused in other study sites, as their parameters integrate complex study site properties from sward structure and species composition to even more complex ones such as past management practices or meteorological conditions. For sward height, Forsmoo et al. (2018) highlighted that 10 sward height field measurements were sufficient to estimate the coefficients of a linear model estimating the sward height based on UAS imagery. To our knowledge, such mixed approaches have not been discussed in the peer-reviewed literature for biomass and forage quality modeling. For these pasture characteristics, the situation is more complex, as our modeling strategy integrates state-of-the-art UAS spectral reflectance information, which is known to still present artefacts hampering repeated quantitative approaches [18]. Among the various potential sources of noise in UAS reflectance products, the radiometric calibration workflow currently promoted by the UAS industry has been criticized by many authors (see, e.g., [61]). This involves the UAS operator taking a picture of a reference grey target before and/or after the flight, while a significant part of the hemisphere can be shaded by the operator. Innovative reflectance sensing approaches have been emerging (e.g., integrating target-less workflows [62]), which will improve the scalability of UAS approaches based on reflectance information.

\section{Conclusions}

The different UAS survey strategies investigated in our study included different sensors (on-board DJI RGB sensors and a multispectral sensor), as well as different approaches in terms of flight survey (nadir and/or oblique images). Despite their relatively low cost (from $1000 €$ for Mavic to $5000 €$ for a Phantom 4 Pro equipped with a Sequoia), these strategies provided accurate sward height, biomass, and forage quality estimates of timothy pastures. Even if their performances were of lower order than the state-of-the-art techniques, such as LiDAR for sward height or hyperspectral sensors for biomass and forage quality modeling, the important trade-off in terms of costs between UAS LiDAR ( $>100,000$ $€)$ or hyperspectral sensors $(>50,000 €)$ promotes the use of such low-cost UAS solutions in real-life applications. This is particularly true for sward height modeling and biomass monitoring, where our low-cost solutions were demonstrated to provide more accurate results than state-of-the-art field approaches such as rising plate meters, at a broader extent and with a finer spatial grain [22-24,26]. Future work should focus on multi-site and multi-temporal forage quality modeling, for which the use of process-based models, such as growth models, could improve the scalability and reproducibility of the approach.

Author Contributions: Conceptualization, A.M. and J.B.; Methodology, A.M. and J.B.; Writing-Original Draft Preparation, A.M.; Writing-Review and Editing, A.M., J.B., L.P., D.S., D.C., K.D.; Supervision, J.B. All authors have read and agreed to the published version of the manuscript.

Funding: This research received no external funding. 
Acknowledgments: Authors would like to thank Cédric Geerts and Kevin Blistein for their help in collecting the field reference data, as well as the "Fourrage Mieux" and the Catholic University of Louvain for providing access to their experimental site in Michamps.

Conflicts of Interest: The authors declare no conflict of interest. 


\section{References}

1. Andriamandroso, A.L.H.; Bindelle, J.; Mercatoris, B.; Lebeau, F. A review on the use of sensors to monitor cattle jaw movements and behavior when grazing. Biotechnol. Agron. Soc. Environ. 2016, 20, 273-286.

2. Debauche, O.; Mahmoudi, S.; Andriamandroso, A.L.H.; Manneback, P.; Bindelle, J.; Lebeau, F. Web-based cattle behavior service for researchers based on the smartphone inertial central. Procedia Comput. Sci. 2017, 110, 110-116. [CrossRef]

3. Laca, E.A. Precision livestock production: Tools and concepts. Rev. Bras. Zootec. 2009, 38, 123-132. [CrossRef]

4. Larson-Praplan, S.; George, M.; Buckhouse, J.; Laca, E. Spatial and temporal domains of scale of grazing cattle. Anim. Prod. Sci. 2015, 55, 284-297. [CrossRef]

5. Andriamandroso, A.; Lebeau, F.; Bindelle, J. Changes in biting characteristics recorded using the inertial measurement unit of a smartphone reflect differences in sward attributes. Precis. Livest. Farming 2015, 15, 283-289.

6. French, P.; O'Brien, B.; Shalloo, L. Development and adoption of new technologies to increase the efficiency and sustainability of pasture-based systems. Anim. Prod. Sci. 2015, 55, 931-935. [CrossRef]

7. Michez, A.; Bauwens, S.; Brostaux, Y.; Hiel, M.-P.; Garré, S.; Lejeune, P.; Dumont, B. How Far Can Consumer-Grade UAV RGB Imagery Describe Crop Production? A 3D and Multitemporal Modeling Approach Applied to Zea mays. Remote Sens. 2018, 10, 1798. [CrossRef]

8. Lopez-Granados, F. Weed detection for site-specific weed management: Mapping and real-time approaches. Weed Res. 2011, 51, 1-11. [CrossRef]

9. Yang, G.; Liu, J.; Zhao, C.; Li, Z.; Huang, Y.; Yu, H.; Xu, B.; Yang, X.; Zhu, D.; Zhang, X.; et al. Unmanned Aerial Vehicle Remote Sensing for Field-Based Crop Phenotyping: Current Status and Perspectives. Front. Plant Sci. 2017, 8, 8. [CrossRef]

10. Bebronne, R.; Michez, A.; Leemans, V.; Vermeulen, P.; Dumont, B.; Mercatoris, B. Characterisation of fungal diseases on winter wheat crop using proximal and remote multispectral imaging. In Precision Agriculture' 19 ; Wageningen Academic Publishers: Cambridge, MA, USA, 2019; pp. 415-421.

11. Lee, H.; Lee, H.-J.; Jung, J.-S.; Ko, H.-J. Mapping Herbage Biomass on a Hill Pasture using a Digital Camera with an Unmanned Aerial Vehicle System. J. Korean Soc. Grassl. Forage Sci. 2015, 35, 225-231. [CrossRef]

12. Lee, H.; Lee, H.; Go, H. Estimating the spatial distribution of Rumex acetosella L. on hill pasture using UAV monitoring system and digital camera. J. Korean Soc. Grassl. Forage Sci. 2016, 36, 365-369. [CrossRef]

13. Michez, A.; Piégay, H.; Lisein, J.; Claessens, H.; Lejeune, P. Classification of riparian forest species and health condition using multi-temporal and hyperspatial imagery from unmanned aerial system. Environ. Monit. Assess. 2016, 188, 188. [CrossRef] [PubMed]

14. Lisein, J.; Michez, A.; Claessens, H.; Lejeune, P. Discrimination of Deciduous Tree Species from Time Series of Unmanned Aerial System Imagery. PLoS ONE 2015, 10, e0141006. [CrossRef] [PubMed]

15. Klosterman, S.; Richardson, A.D. Observing spring and fall phenology in a deciduous forest with aerial drone imagery. Sensors 2017, 17, 2852. [CrossRef] [PubMed]

16. Herrmann, I.; Bdolach, E.; Montekyo, Y.; Rachmilevitch, S.; Townsend, P.A.; Karnieli, A. Assessment of maize yield and phenology by drone-mounted superspectral camera. Precis. Agric. 2020, 21, 51-76. [CrossRef]

17. Klosterman, S.; Melaas, E.; Wang, J.A.; Martinez, A.; Frederick, S.; O’Keefe, J.; Orwig, D.A.; Wang, Z.; Sun, Q.; Schaaf, C.; et al. Fine-scale perspectives on landscape phenology from unmanned aerial vehicle (UAV) photography. Agric. For. Meteorol. 2018, 248, 397-407. [CrossRef]

18. Manfreda, S.; McCabe, M.F.; Miller, P.E.; Lucas, R.; Pajuelo Madrigal, V.; Mallinis, G.; Ben Dor, E.; Helman, D.; Estes, L.; Ciraolo, G.; et al. On the use of unmanned aerial systems for environmental monitoring. Remote Sens. 2018, 10, 641. [CrossRef]

19. Savian, J.V.; Schons, R.M.T.; Marchi, D.E.; de Freitas, T.S.; da Silva Neto, G.F.; Mezzalira, J.C.; Berndt, A.; Bayer, C.; de Faccio Carvalho, P.C. Rotatinuous stocking: A grazing management innovation that has high potential to mitigate methane emissions by sheep. J. Clean. Prod. 2018, 186, 602-608. [CrossRef]

20. Andriamandroso, A.; Castro Muñoz, E.; Blaise, Y.; Bindelle, J.; Lebeau, F. Differentiating pre-and post-grazing pasture heights using a 3D camera: A prospective approach. Precis. Livest. Farming 2017, 17, 238-246. Available online: https://orbi.uliege.be/handle/2268/215034 (accessed on 21 May 2020). 
21. Grüner, E.; Astor, T.; Wachendorf, M. Biomass Prediction of Heterogeneous Temperate Grasslands Using an SfM Approach Based on UAV Imaging. Agronomy 2019, 9, 54. [CrossRef]

22. Forsmoo, J.; Anderson, K.; Macleod, C.J.; Wilkinson, M.E.; Brazier, R. Drone-based structure-from-motion photogrammetry captures grassland sward height variability. J. Appl. Ecol. 2018, 55, 2587-2599. [CrossRef]

23. Insua, J.R.; Utsumi, S.A.; Basso, B. Estimation of spatial and temporal variability of pasture growth and digestibility in grazing rotations coupling unmanned aerial vehicle (UAV) with crop simulation models. PLoS ONE 2019, 14, e0212773. [CrossRef]

24. Bareth, G.; Schellberg, J. Replacing manual rising plate meter measurements with low-cost UAV-derived sward height data in grasslands for spatial monitoring. PFG-J. Photogramm. Remote Sens. Geoinf. Sci. 2018, 86, 157-168. [CrossRef]

25. Bendig, J.; Yu, K.; Aasen, H.; Bolten, A.; Bennertz, S.; Broscheit, J.; Gnyp, M.L.; Bareth, G. Combining UAV-based plant height from crop surface models, visible, and near infrared vegetation indices for biomass monitoring in barley. Int. J. Appl. Earth Obs. Geoinf. 2015, 39, 79-87. [CrossRef]

26. Michez, A.; Lejeune, P.; Bauwens, S.; Herinaina, A.A.L.; Blaise, Y.; Castro Muñoz, E.; Lebeau, F.; Bindelle, J. Mapping and monitoring of biomass and grazing in pasture with an unmanned aerial system. Remote Sens. 2019, 11, 473. [CrossRef]

27. Yuan, W.; Li, J.; Bhatta, M.; Shi, Y.; Baenziger, P.S.; Ge, Y. Wheat height estimation using LiDAR in comparison to ultrasonic sensor and UAS. Sensors 2018, 18, 3731. [CrossRef]

28. Lisein, J.; Pierrot-Deseilligny, M.; Bonnet, S.; Lejeune, P. A Photogrammetric Workflow for the Creation of a Forest Canopy Height Model from Small Unmanned Aerial System Imagery. Forests 2013, 4, 922-944. [CrossRef]

29. Gil-Docampo, M.; Arza-García, M.; Ortiz-Sanz, J.; Martínez-Rodríguez, S.; Marcos-Robles, J.L.; Sánchez-Sastre, L.F. Above-ground biomass estimation of arable crops using UAV-based SfM photogrammetry. Geocarto Int. 2019, 35, 687-699. [CrossRef]

30. Batistoti, J.; Marcato Junior, J.; Ítavo, L.; Matsubara, E.; Gomes, E.; Oliveira, B.; Souza, M.; Siqueira, H.; Salgado Filho, G.; Akiyama, T.; et al. Estimating Pasture Biomass and Canopy Height in Brazilian Savanna Using UAV Photogrammetry. Remote Sens. 2019, 11, 2447. [CrossRef]

31. Capolupo, A.; Kooistra, L.; Berendonk, C.; Boccia, L.; Suomalainen, J. Estimating plant traits of grasslands from UAV-acquired hyperspectral images: A comparison of statistical approaches. ISPRS Int. J. Geo-Inf. 2015, 4, 2792-2820. [CrossRef]

32. Wijesingha, J.; Astor, T.; Schulze-Brüninghoff, D.; Wengert, M.; Wachendorf, M. Predicting Forage Quality of Grasslands Using UAV-Borne Imaging Spectroscopy. Remote Sens. 2020, 12, 126. [CrossRef]

33. Näsi, R.; Viljanen, N.; Oliveira, R.; Kaivosoja, J.; Niemeläinen, O.; Hakala, T.; Markelin, L.; Nezami, S.; Suomalainen, J.; Honkavaara, E. Optimizing Radiometric Processing and Feature Extraction of Drone Based Hyperspectral Frame Format Imagery for Estimation of Yield Quantity and Quality of A Grass Sward. Int. Arch. Photogramm. Remote. Sens. Spat. Inf. Sci. 2018, 42, 1305-1330. [CrossRef]

34. Vong, C.N.; Zhou, J.; Tooley, J.A.; Naumann, H.D.; Lory, J.A. Estimating Forage Dry Matter and Nutritive Value Using UAV- and Ground-Based Sensors-A Preliminary Study; ASABE: St. Joseph, MI, USA, 2019; p. 1.

35. Na, S.-I.; Kim, Y.-J.; Park, C.-W.; So, K.-H.; Park, J.-M.; Lee, K.-D. Evaluation of feed value of IRG in middle region using UAV. Korean Soc. Soil Sci. Fertil. 2017, 50, 391-400.

36. Barnes, R.F.; Nelson, C.; Collins, M.; Moore, K.J. Forages. In Volume 1: An Introduction to Grassland Agriculture; John Wiley \& Sons: Hoboken, NJ, USA, 2003.

37. James, M.R.; Robson, S.; d'Oleire-Oltmanns, S.; Niethammer, U. Optimising UAV topographic surveys processed with structure-from-motion: Ground control quality, quantity and bundle adjustment. Geomorphology 2017, 280, 51-66. [CrossRef]

38. Javernick, L.; Brasington, J.; Caruso, B. Modeling the topography of shallow braided rivers using Structure-from-Motion photogrammetry. Geomorphology 2014, 213, 166-182. [CrossRef]

39. Gonçalves, J.; Henriques, R. UAV photogrammetry for topographic monitoring of coastal areas. ISPRS J. Photogramm. Remote Sens. 2015, 104, 101-111. [CrossRef]

40. Vautherin, J.; Rutishauser, S.; Schneider-Zapp, K.; Choi, H.F.; Chovancova, V.; Glass, A.; Strecha, C. Photogrammetric accuracy and modeling of rolling shutter cameras. ISPRS Ann. Photogramm. Remote Sens. Spat. Inf. Sci. 2016, 3, 139-146. [CrossRef] 
41. Tucker, C.J. Red and photographic infrared linear combinations for monitoring vegetation. Remote Sens. Environ. 1978, 8, 127-150. [CrossRef]

42. Metternicht, G. Vegetation indices derived from high-resolution airborne videography for precision crop management. Int. J. Remote Sens. 2003, 24, 2855-2877. [CrossRef]

43. Gitelson, A.A.; Viña, A.; Arkebauer, T.J.; Rundquist, D.C.; Keydan, G.; Leavitt, B. Remote estimation of leaf area index and green leaf biomass in maize canopies. Geophys. Res. Lett. 2003, 30, 30. [CrossRef]

44. Gitelson, A.A.; Kaufman, Y.J.; Stark, R.; Rundquist, D. Novel algorithms for remote estimation of vegetation fraction. Remote Sens. Environ. 2002, 80, 76-87. [CrossRef]

45. Rouse, J., Jr.; Haas, R.; Schell, J.; Deering, D. Monitoring vegetation systems in the Great Plains with ERTS. NASA Spec. Publ. 1974, 351, 309.

46. Barnes, E.; Clarke, T.; Richards, S.; Colaizzi, P.; Haberland, J.; Kostrzewski, M.; Waller, P.; Choi, C.; Riley, E.; Thompson, T.; et al. Coincident detection of crop water stress, nitrogen status and canopy density using ground based multispectral data. In Proceedings of the Fifth International Conference on Precision Agriculture, Bloomington, MN, USA, 16-19 July 2000; Volume 1619.

47. Moges, S.; Raun, W.; Mullen, R.; Freeman, K.; Johnson, G.; Solie, J. Evaluation of green, red, and near infrared bands for predicting winter wheat biomass, nitrogen uptake, and final grain yield. J. Plant Nutr. 2005, 27, 1431-1441. [CrossRef]

48. Sripada, R.P.; Heiniger, R.W.; White, J.G.; Meijer, A.D. Aerial Color Infrared Photography for Determining Early In-Season Nitrogen Requirements in Corn. Agron. J. 2006, 98, 968-977. [CrossRef]

49. Gitelson, A.A.; Gritz, Y.; Merzlyak, M.N. Relationships between leaf chlorophyll content and spectral reflectance and algorithms for non-destructive chlorophyll assessment in higher plant leaves. J. Plant Physiol. 2003, 160, 271-282. [CrossRef]

50. Serrano, L.; Filella, I.; Penuelas, J. Remote sensing of biomass and yield of winter wheat under different nitrogen supplies. Crop. Sci. 2000, 40, 723-731. [CrossRef]

51. Rueda-Ayala, V.P.; Peña, J.M.; Höglind, M.; Bengochea-Guevara, J.M.; Andújar, D. Comparing UAV-Based Technologies and RGB-D Reconstruction Methods for Plant Height and Biomass Monitoring on Grass Ley. Sensors 2019, 19, 535. [CrossRef]

52. Estornell, J.; Ruiz, L.; Velázquez-Martí, B.; Hermosilla, T. Analysis of the factors affecting LiDAR DTM accuracy in a steep shrub area. Int. J. Digit. Earth 2011, 4, 521-538. [CrossRef]

53. Albl, C.; Sugimoto, A.; Pajdla, T. Degeneracies in rolling shutter sfm. In Proceedings of the European Conference on Computer Vision, Amsterdam, The Netherlands, 8-16 October 2016; Springer: Berlin/Heidelberg, Germany, 2016; pp. 36-51.

54. Strecha, C.; Zoller, R.; Rutishauser, S.; Brot, B.; Schneider-Zapp, K.; Chovancova, V.; Krull, M.; Glassey, L. Quality assessment of $3 \mathrm{~d}$ reconstruction using fisheye and perspective sensors. ISPRS Ann. Photogramm. Remote Sens. Spat. Inf. Sci. 2015, 2, 215-222. [CrossRef]

55. Pagliari, D.; Pinto, L. Use of fisheye parrot bebop 2 images for $3 \mathrm{~d}$ modelling using commercial photogrammetric software. Int. Arch. Photogramm. Remote Sens. Spat. Inf. Sci. 2018, 42, 813-820. [CrossRef]

56. Viljanen, N.; Honkavaara, E.; Näsi, R.; Hakala, T.; Niemeläinen, O.; Kaivosoja, J. A Novel Machine Learning Method for Estimating Biomass of Grass Swards Using a Photogrammetric Canopy Height Model, Images and Vegetation Indices Captured by a Drone. Agriculture 2018, 8, 70. [CrossRef]

57. Lussem, U.; Bolten, A.; Menne, J.; Gnyp, M.; Bareth, G. Ultra-high spatial resolution UAV-based imagery to predict biomass in temperate grasslands. Int. Arch. Photogramm. Remote Sens. Spat. Inf. Sci. 2019, 4213, 443-447. [CrossRef]

58. Näsi, R.; Viljanen, N.; Kaivosoja, J.; Alhonoja, K.; Hakala, T.; Markelin, L.; Honkavaara, E. Estimating biomass and nitrogen amount of barley and grass using UAV and aircraft based spectral and photogrammetric 3D features. Remote Sens. 2018, 10, 1082. [CrossRef]

59. Hakl, J.; Hrevušová, Z.; Hejcman, M.; Fuksa, P. The use of a rising plate meter to evaluate lucerne (Medicago sativa L.) height as an important agronomic trait enabling yield estimation. Grass Forage Sci. 2012, 67, 589-596. [CrossRef]

60. Sanderson, M.A.; Rotz, C.A.; Fultz, S.W.; Rayburn, E.B. Estimating forage mass with a commercial capacitance meter, rising plate meter, and pasture ruler. Agron. J. 2001, 93, 1281-1286. [CrossRef] 
61. Aasen, H.; Honkavaara, E.; Lucieer, A.; Zarco-Tejada, P.J. Quantitative remote sensing at ultra-high resolution with UAV spectroscopy: A review of sensor technology, measurement procedures, and data correction workflows. Remote Sens. 2018, 10, 1091. [CrossRef]

62. Schneider-Zapp, K.; Cubero-Castan, M.; Shi, D.; Strecha, C. A new method to determine multi-angular reflectance factor from lightweight multispectral cameras with sky sensor in a target-less workflow applicable to UAV. Remote Sens. Environ. 2019, 229, 60-68. [CrossRef]

C 2020 by the authors. Licensee MDPI, Basel, Switzerland. This article is an open access article distributed under the terms and conditions of the Creative Commons Attribution (CC BY) license (http://creativecommons.org/licenses/by/4.0/). 